\section{Museum cuts spark protest}

Ottawa. A major restructuring of the Canadian Museum of Nature and the decision to lay off about 20 per cent of its staff are causing concern among environmental organizations, museum professionals and individuals.

Staff cuts announced this summer include nine researchers (seven scientists and two assistants). Others who will lose their jobs are six cction e xperts, three library staff, and thirteen members of the education and dy di vision, as well as six individuals in business operations and publishing.

The changes at the museum are taking place following revisions to its mandate that were introduced when the museum - formerly part of the National Museums of Canada Corporation - became a separate Crown corporation in 1990.

The museum's director, Alan R. Emery, says that its new mandate, which is similar to that now being followed by Britain's Natural History Museum and similar institutions in other countries, means that all research can no longer be strictly curiosity driven, and that as a result it is being reorientated away from primarily disciplinary interests

Emery has therefore created a series of multidisciplinary 'programmes' based on broad issues considered to be of interest to both science and society, rather than what he describes as "the simple survey type of work that was traditionally done in this institution".

Another revision to the museum's mandate has been the requirement that it should become more commercially minded. In particular, says Emery, the museum is now

required to seek funding through admission charges to the public, and through private sources. In order to encourage what he describes as a "business thrust", it was given the legal right to earn money and to keep it to support its programme, rather than returning it to the Crown as previously.

Yet although the mandate of the museum has been enlarged, its public funding has been reduced. The current budget of $\mathrm{C} \$ 18$ million is about C $\$ 3$ million less than it was four years ago; in the meantime, the museum's mandate has been enlarged. And Emery says the staff cuts are a direct result of the fall in federal funding.

Following the announcement of the redundancies, the museum staff has requested the minister of the new Heritage Department, formed recently by Mrs Kim Campbell, the Prime Minister, to order a stay on restructuring and an investigation of the museum's management.

Their demands are being supported by an environmental network, called "True Friends of Nature", which is being coordinated by the Sierra Club. The network has appealed to the public to "save" the museum, which, it says, "is experiencing a serious and profound crisis".

The network also claims that "fundamental flaws inherent in the governance of the museum ... are in large part responsible" for the changes. It says too much power is concentrated in the hands of the director and chairman of the board of trustees, and there is no participation in museum policy by interested groups such as itself and by the museum's staff.

David Spurgeon

\title{
Biotech finds new voice
}

Washington. Health-care companies in the state of California, home to more nearly 30 per cent of the US biotechnology industry, hope to be able to speak with one voice on key issues of public policy such as President Bill Clinton's proposed reforms with the recent formation of a new California Healthcare Institute.

Located temporarily at the offices of Genentech Inc. in South San Francisco, the new institute plans to set up a permanent office in San Diego. It currently has 59 members drawn primarily from the biotechnology, medical device and pharmaceutical industries, although academic institutions are also eligible to join.

The president's proposals for health-care reform, which are expected to be announced in outline form later this month, are at the top of the institute's agenda. But its officials also plan to consider problems ranging from the disposal of low-level radioactive waste to future funding levels for the state's universities and other educational establishments.

Charles C. Edwards, former president and chief executive officer of Scripps Institutions of Medicine and Science, has been chosen to head the institute. Edwards is no stranger to the workings of Washington, having served on numerous government advisory panels, and as commissioner of the US Food and Drug Administration between 1969 and 1973

One of the first tasks of the institute has been to conduct a survey of 138 of the state's largest health-care companies, in an attempt to quantify the economic contribution and importance of the industry to California. Full details of the survey are expected later this month. Preliminary findings indicate that the biomedical companies founded since 1988 account for 10 per cent of the state's new jobs during this period.

Diane Gershon

\section{US wetlands plan meets with a mixed reaction}

Washington. The Clinton administration has announced a new policy that attempts to end the debate over the "wetlands" of the United States - areas that include swamps, ponds, estuaries and other watery habitats that support many endangered species and naturally control pollution and floods. In doing so, however, it has still failed to clarify precisely what the term means.

Government estimates show that the United States is losing about 300,000 of its total 270 million acres of wetland habitat each year. In a series of attempts to halt this process, both the Reagan and Bush administrations have continually revised their wetlands policies over the past decade.

The result, however, was to leave scientists, conservationists, developers and landuse officials squabbling over which lands should be protected. In the process, definitions have become so unclear that many of the nine federal agencies that oversee wetlands now use vastly different standards in qualifying them for protection.

The Clinton administration has now announced what it called a "balanced, common-sense, workable set of improvements" for wetlands. One aim is to eliminate loopholes that have allowed developers to build shopping malls, office buildings and housing tracts in certain wetlands areas. Also, Clinton's plans would reverse a Bush administration proposal that would have allowed development on 1.7 million acres (or one per cent) of Alaska's wetlands, including 345,000 acres of fragile coastal areas.

Nonetheless, the NWF and other conservationist groups have still attacked most of Clinton's other wetlands directives, claiming that they make too many concessions to developers and farmers. For example, they criticize the plan's call for "mitigation banking" by which a wetland may be developed if another wetland preserve is created elsewhere.

The new plan also fails to bridge what many see as a gap between science and politics, by leaving the task of crafting a precise and lasting definition of the concept of wetlands to a scientific committee formed by the National Academy of Science's National Research Council.

The 18-member committee will hold its first meeting in Washington later this month. Its task is to study regional differences among wetlands, and discuss what levels of water cover, soil moisture and vegetation should be used in delineating the habitats.

The committee is due to complete its recommendations in September 1994. Until then, the various federal agencies overseeing wetlands will continue to follow patchworked standards in carrying out the administration's new policies. 